\title{
Localization of metabotropic glutamate receptors in the outer plexiform layer of the goldfish retina
}

\author{
Christina Joselevitch • Jan Klooster • \\ Maarten Kamermans
}

Received: 19 June 2007 / Accepted: 8 August 2007 / Published online: 29 September 2007

(C) Springer-Verlag 2007

\begin{abstract}
We studied the localization of metabotropic glutamate receptors (mGluRs) in the goldfish outer plexiform layer by light-and electron-microscopical immunohistochemistry. The mGluR $1 \alpha$ antibody labeled putative ON-type bipolar cell dendrites and horizontal cell processes in both rod spherules and cone triads. Immunolabeling for mGluR $2 / 3$ was absent in the rod synaptic complex but was found at horizontal cell dendrites directly opposing the cone synaptic ribbon. The mGluR5 antibody labeled Müller cell processes wrapping rod terminals and horizontal cell somata. The mGluR7 antibody labeled mainly horizontal cell dendrites invaginating rods and cones and some putative bipolar cell dendrites in the cone synaptic complex. The finding of abundant expression of various mGluRs in bipolar and horizontal cell dendrites suggests multiple sites of glutamatergic modulation in the outer retina.
\end{abstract}

Keywords Metabotropic glutamate receptor - Retina .

Electron microscopy · Immunohistochemistry - Bipolar cell . Horizontal cell · Goldfish, Carassius auratus (Teleostei)

\section{Introduction}

Stimulation of vertebrate photoreceptors by light decreases the release of glutamate (Cervetto and MacNichol 1972;

Financial support for this work was provided by Conselho Nacional de Pesquisa (CNPq), Brazil (grant 200915/98-3 to C.J.)

C. Joselevitch $\cdot$ J. Klooster $\cdot$ M. Kamermans $(\triangle)$

Retinal Signal Processing,

The Netherlands Institute for Neuroscience (KNAW),

Meibergdreef 47,

1105 BA Amsterdam, The Netherlands

e-mail: m.kamermans@nin.knaw.nl
Murakami et al. 1972; Kaneko and Shimazaki 1976), which is sensed by glutamate receptors (GluRs) in the dendrites of second-order neurons. Glutamate receptors are roughly divided into ionotropic and metabotropic receptors (Eccles and McGeer 1979). Ionotropic receptors (iGluRs) form an integral ion channel, whereas metabotropic receptors (mGluRs) mediate responses through indirect mechanisms involving signal transduction cascades.

So far, eight different mGluRs have been cloned and classified into three groups based on their sequence similarities, second-messenger cascade, and pharmacology: group I comprises mGluR1 (Houamed et al. 1991; Masu et al. 1991) and mGluR5 (Abe et al. 1992) and their splice variants (1a-d and $5 \mathrm{a}-\mathrm{b}$ ); group II contains mGluR2 and mGluR3 (Tanabe et al. 1992; Tanabe et al. 1993); and group III includes mGluR4 (Tanabe et al. 1993), mGluR6 (Nakajima et al. 1993), mGluR7 (Okamoto et al. 1994; Saugstad et al. 1994), and mGluR8 (Duvoisin et al. 1995), and their splice variants ( $4 a-b, 7 a-b, 6 a-b$, and $8 \mathrm{a}-\mathrm{b})$. The lack of specific pharmacological tools to distinguish between mGluRs within a group makes it difficult to link a particular receptor type to a certain response property (for reviews, see Thoreson and Ulphani 1995; Schoepp et al. 1999).

In the retina, mGluRs play an important role in the transmission and modulation of visual signals. Light responses of ON-type bipolar cells (ON BCs) of a number of species, for instance, are sensitive to substances/drugs that target group III mGluRs (Shiells et al. 1981; Slaughter and Miller 1981; Thoreson and Miller 1993). The receptor activated by these drugs is most likely mGluR6 (Nakajima et al. 1993; Akazawa et al. 1994; Masu et al. 1995; Ueda et al. 1997; Vardi and Morigiwa 1997; Laurie et al. 1997; Vardi et al. 2000). In fish, amphibians, and mammals, group III mGluRs modulate the glutamate release of cones (Koulen et al. 1999; Hirasawa 
et al. 2002; Hosoi et al. 2005). Furthermore, pharmacological activation of both group I and group III mGluRs modulates horizontal cell (HC) responses (Nawy et al. 1989; Takahashi and Copenhagen 1992; Linn and Gafka 1999), suggesting that multiple mGluRs must be present in the fish outer plexiform layer (OPL).

At the moment, however, data available on the identity and distribution of the various mGluRs in the teleost outer retina are scarce (Yazulla et al. 2001; Klooster et al. 2001). We have therefore performed a light and electron microscopy study of the mGluRs present in the goldfish OPL. An antibody against the ON BC marker, protein kinase C (PKC; Negishi et al. 1988; Suzuki and Kaneko 1990; Yazulla and Studholme 1992), has been used in order to identify possible localization in mixed-input ON BCs (ON MBCs).

\section{Materials and methods}

\section{Subjects}

Goldfish (Carassius auratus), 12-15 cm standard body length, were obtained from a commercial supplier and maintained at $16^{\circ} \mathrm{C}$ in aerated tanks filled with tap water circulating through a biological filter system. The fish were fed and kept on a $12 \mathrm{~h} / 12 \mathrm{~h}$ light-dark cycle. All animal experiments were approved by the ethical committee of the Royal Netherlands Academy of Arts and Sciences, acting in accordance with the European Communities Council Directive of 24 November 1986 (86/609/EEC).

\section{Preparation}

Dissections took place early in the morning (between 7 a.m. and 9 a.m.) under ambient light. The fish used in this study were therefore all in the light phase of their circadian regime. After cervical transection, the cornea and lens of light-adapted animals were removed, and the remaining eyecups were cut in half through the equator. Half-eyecups were placed vitreousside-down on a Millipore filter $(13 \mathrm{~mm}$ diameter, $8 \mu \mathrm{m}$ pore size; Millipore, Amsterdam, The Netherlands) placed on a filter holder. Suction was applied to remove the vitreous; the sclera and retinal pigment epithelium were peeled away.

\section{Light microscopy}

Retinas were fixed at room temperature for $10 \mathrm{~min}$ in $0.1 \mathrm{M}$ phosphate-buffered $4 \%$ paraformaldehyde ( $\mathrm{pH} 6.5$ ) and for another $10 \mathrm{~min}$ in $0.1 \mathrm{M}$ sodium carbonate-buffered $4 \%$ paraformaldehyde ( $\mathrm{pH}$ 10.4). These short fixation times were chosen to prevent loss of antigenicity. After being rinsed in $0.1 \mathrm{M}$ phosphate buffer ( $\mathrm{PB}, \mathrm{pH}$ 7.4), the tissue was cryoprotected at room temperature for $30 \mathrm{~min}$ in $\mathrm{PB}$ containing $12.5 \%$ sucrose and for $1-2 \mathrm{~h}$ in PB containing $25 \%$ sucrose.

The pieces of retina, still attached to the filter, were embedded in Tissue Tek (Sakura Finetek Europe, Zouterwoude, The Netherlands) in an aluminum boat and frozen in liquid nitrogen. Sections $(8-10 \mu \mathrm{m}$ thick) were cut in a cryostat, mounted on poly-L-lysine-coated slides (Menzel-Gläser, Braunschweig, Germany), dried and stored in a non-frost-free freezer at $-20^{\circ} \mathrm{C}$ until use.

Retinal sections were washed $(2 \times, 10 \mathrm{~min})$ in phosphatebuffered saline (PBS), blocked for 20 min in PBS with $2 \%$ normal goat serum (NGS; Jackson ImmunoResearch Lab, West Grove, USA), incubated for $18-48 \mathrm{~h}$ with the primary antibody (for dilutions, see Table 1) in PBS containing $0.3 \%$ Triton $\mathrm{X}-100$ and $5 \% \mathrm{NGS}$ at $4{ }^{\circ} \mathrm{C}$. After several washes $(15 \mathrm{~min}, 3 \times)$ in PBS, sections were incubated in the secondary antibodies diluted in PBS containing $0.3 \%$ Triton $\mathrm{X}-100$ for $30 \mathrm{~min}$ at $37^{\circ} \mathrm{C}$ (Cy3-conjugated antibody: 1:500, Alexa-conjugated antibody: 1:600).

Sections were cover-slipped with Vectashield (Vector Labs, Burlingame, USA) and stored at $-20^{\circ} \mathrm{C}$. Slides were observed on a Leica DMRD (Leica Microsystems, Wetzlar, Germany) fluorescence microscope equipped with filter sets that were designed for fluorescein isothiocyanate and $\mathrm{Cy} 3$. Sections from double-label experiments were observed on an inverted Zeiss Axiovert $100 \mathrm{M}$ microscope equipped with the LSM 510 META laser scanning confocal module (Carl Zeiss Jena, Jena, Germany).

Two types of controls were performed. To control for unspecific labeling attributable to secondary antibodies, experiments were performed by omitting the primary antibody. This eliminated all labeling. To control for unspecific labeling attributable to the primary antibodies, preadsorption experiments were performed by mixing, in a 20 -fold molar excess, a synthetic peptide having the amino acid sequence against which each mGluR antibody had been raised (see below) with the corresponding primary antibody overnight at $4^{\circ} \mathrm{C}$. Incubation proceeded as previously described, with the same concentrations for the primary antisera. Labeling was also completely eliminated in these preadsorption controls.

\section{Electron microscopy}

The same fixation and cryoprotection procedures were used as described for light microscopy. The retinas were peeled off the filter and embedded in Tissue Tek (Sakura Finetek Europe, Zouterwoude, The Netherlands) in an aluminum boat. The boat was frozen in liquid nitrogen. Transverse frozen sections (30-40 $\mu \mathrm{m}$ thick) were obtained on a freezing microtome and collected in $\mathrm{PB}$ at room temperature (equivalent to freeze-thawing).

The retinal sections were incubated for $72 \mathrm{~h}$ with diluted antisera (for dilutions, see Table 1). After being rinsed, the 


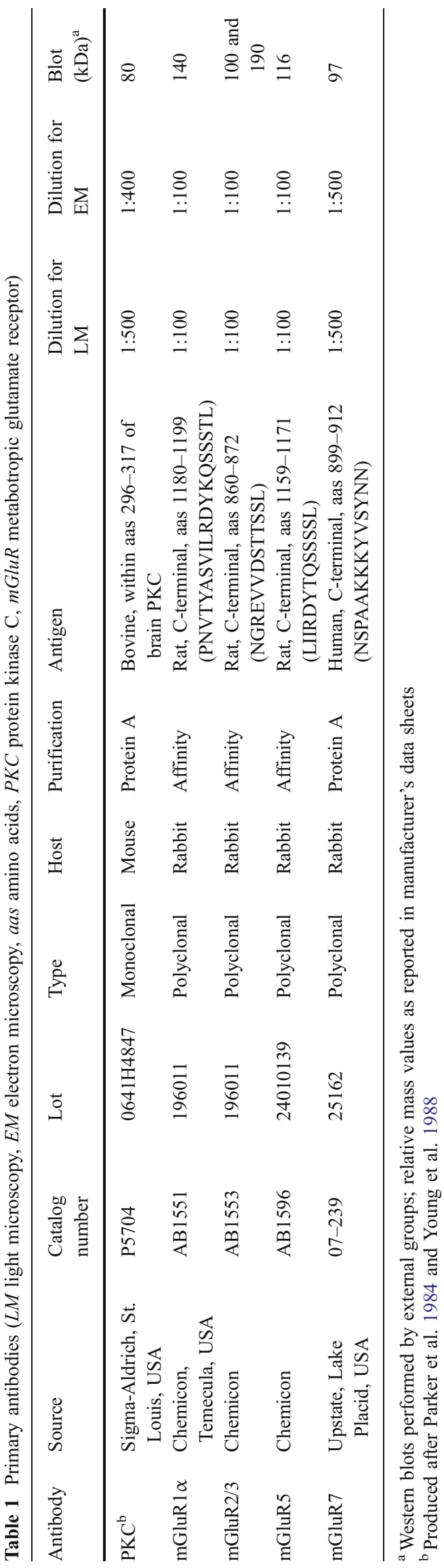

tissue was incubated in a poly-horseradish-peroxidase (HRP)conjugated goat anti-mouse or anti-rabbit IgG (PowerVision, ImmunoVision Technologies, Daly City, USA). To visualize the peroxidase, the material was incubated in a TRIS-HCl diaminobenzidine (DAB, $0.05 \%$ ) solution containing $0.03 \%$ $\mathrm{H}_{2} \mathrm{O}_{2}$. The DAB reaction product was subsequently intensified by the gold-substituted silver peroxidase method (Gorcs et al. 1986).

Sections were rinsed in sodium cacodylate buffer $0.1 \mathrm{M}$ (pH 7.4) and post-fixed for $20 \mathrm{~min}$ in $1 \% \mathrm{OsO}_{4}$ supplemented with $1.5 \%$ potassium ferricyanide in sodium cacodylate buffer $0.1 \mathrm{M}$ ( $\mathrm{pH}$ 7.4). After being rinsed in sodium cacodylate buffer, the material was dehydrated and embedded in epoxy resin. Ultrathin sections were observed in a Philips EM201 electron microscope (Philips, Eindhoven, The Netherlands) and/or Technai (CM) 12 electron microscope (FEI Company, Eindhoven, The Netherlands). Sections examined with the Philips electron microscope were counter-stained with uranyl acetate and lead citrate.

\section{Sampling and production of photomicrographs}

At least 20 retinal sections obtained from a minimum of five animals were used for a given light microscopy or electronmicroscopy experiment (i.e., single-immunolabeling at the light-microscopy level for mGluR $1 \alpha$ ). About five photomicrographs were taken from the most representative sections in each experiment.

Light micrographs of the single-label experiments were acquired as TIFF files directly from the Leica microscope by using a Leica $350 \mathrm{~F}$ digital B/W camera $(1284 \times 1028$ pixels, 72 ppi). Light micrographs of the double-label experiments were acquired as TIFF files from the Zeiss LSM 510 META $(1048 \times 1024$ pixels, 72 ppi).

For electron-microscopy experiments, the same number of retinal sections/animals as described above was examined at the light-microscopical level; labeled sections were chosen for ultra-thin sectioning. A minimum of 40 photoreceptor terminals were observed per ultra-thin section. Micrographs $(n=10-30)$ were taken from these sections, depending on the presence and amount of labeling.

Electron micrographs obtained with the FEI electron microscope were directly acquired as TIFF files (1024x 1024 pixels, 72 ppi). Electron micrographs obtained from the Philips electron microscope were first printed from the negatives for analysis. The negatives of the prints that were selected for publication were scanned on a sprint scan 4000 scanner (Polaroid Nederland, Breda, The Netherlands) and acquired as TIFF files at 600 ppi.

All TIFF files were resampled at $400 \mathrm{ppi}$ and subsequently re-sized and optimized for brightness and contrast by using Photoshop (Adobe Systems, San Jose, USA). 
Immunochemicals

The primary antibodies used in this study were purchased from Chemicon International (Temecula, USA), SigmaAldrich (St. Louis, USA), and Upstate (Lake Placid, USA). Details of these antibodies are listed in Table 1. Goat antimouse Alexa was obtained from Molecular Probes (Breda, The Netherlands) and goat anti-rabbit Cy3 from Jackson ImmunoResearch Lab (West Grove, USA). For preadsorption controls, custom-made peptides were obtained from Eurogentec (Seraing, Belgium).

\section{Western blotting}

Goldfish retinas and brains were homogenized with a Teflon pestle in ice-cold PBS (pH 7.4) containing a tablet of protease inhibitor cocktail (Boehringer Mannheim, Mannheim, Germany) per $50 \mathrm{ml} \mathrm{PBS}$. After homogenization, a TRIS-buffered sample (pH 6.8) solution was added, with final concentrations of: $2 \%$ SDS, $5 \% \beta$-mercaptoethanol, $10 \%$ glycerol, $0.005 \%$ bromophenol blue. The samples were boiled for $2 \mathrm{~min}$ and centrifuged for $10 \mathrm{~min}$ at $14,600 \mathrm{~g}$; supernatants were stored at $-20^{\circ} \mathrm{C}$ until use. The diluted samples were boiled for $2 \mathrm{~min}(3 \times)$, cooled, and then spun in a microfuge at $14,600 \mathrm{~g}$.

For sodium dodecyl-sulfate polyacrylamide gel electrophoresis, samples were run through a polyacrylamide stacking gel at $20 \mathrm{~mA}$ and through a $13 \%$ polyacrylamide gel at $30 \mathrm{~mA}$. Protein standards (Bio-Rad Laboratories, Veenendaal, The Netherlands) were run in adjacent lanes. Gels were electroblotted on a poly-vinylidene-di-fluoride blot membrane (Millipore) overnight at a constant current of $80 \mathrm{~mA}$. After being rinsed with a $0.5 \mathrm{M}$ TRIS buffer containing $1.5 \mathrm{M} \mathrm{NaCl}$ and $5 \%$ Tween 200 , the membrane was blocked in the same buffer containing $2 \%$ dry milk for $1 \mathrm{~h}$.

Subsequently, the membrane was incubated for $1 \mathrm{~h}$ in the primary antibodies $(1: 100)$, washed in the TRIS buffer, incubated in an HRP-conjugated goat anti-rabbit $\operatorname{IgG}(1: 5000$; Santa Cruz Biotechnology, Santa Cruz, USA), and washed in PBS. The immunoreaction was visualized by enhanced chemiluminescence (ECL, Amersham, Arlington Heights, USA) by using Kodak film. Exposures times were between 1 and $5 \mathrm{~min}$.

\section{Results}

In this study, we aimed at a qualitative description of the mGluR composition in the goldfish OPL. To have a parameter for comparisons with regard to $\mathrm{ON} \mathrm{BC}$ labeling with the antibodies against the various mGluRs, we first investigated the immunoreactivity pattern yielded by the PKC antibody, a widely used $\mathrm{ON} \mathrm{BC}$ marker. Therefore, the labeling for PKC will be described first, followed by each of the mGluRs studied.
Immunolabeling for PKC

The PKC antibody was characterized by Western blot previously in a number of studies (Negishi et al. 1988; Suzuki and Kaneko 1990; Yazulla and Studholme 1992) and yielded similar results in various species (Table 1).

Light microscopy Immunolabeling for PKC in the goldfish retina at the light-microscopical level has been described in detail elsewhere (Suzuki and Kaneko 1990). Briefly, two populations of ON BCs were labeled: cells with small somata in the middle of the inner nuclear layer (INL) and small axonal terminations (cone-driven ON BCs), and cells with large flask-shaped somata and bulbous axon terminals (ON MBCs).

Electron microscopy: rod synapses In the rod synaptic complex, the antibody against PKC labeled invaginating dendrites at the central position and processes at some distance from the ribbon (Fig. 1a-c, arrowheads). The labeled structures were elongated (Fig. 1a), u-shaped (Fig. 1b), or round (Fig. 1c) and were found either directly opposite to the synaptic ribbon (Fig. 1a,b) or a little distance away from it (Fig. 1c). Dendrites with these characteristics and at these locations in the cyprinid retina were previously shown to belong to ON MBCs (Scholes 1975; Stell 1967, 1976, 1978; Saito et al. 1983, 1985; Klooster et al. 2001; Yazulla and Studholme 2001).

Lateral processes immediately adjacent to the pre-synaptic ridge, previously classified as dendrites of rod-driven HCs (Stell 1967, 1976; Scholes 1975) were not labeled (Fig. 1a-c, arrows). Some invaginating processes were also not labeled (Fig. 1a,c, asterisks); their position and fine structure, in combination with the lack of labeling, suggested that they were either dendrites of OFF-type MBCs or rod-driven HCs (Stell 1967, 1976; Saito et al. 1983, 1985).

Electron microscopy: cone synapses $\mathrm{PKC}$-immunoreactive structures were not abundant in the vicinity of the cone pedicles. When present, the labeled structures were never associated with the synaptic ribbon but were instead localized at the base of the cone pedicle (Fig. 1d,e, arrowheads). These were probably $\mathrm{ON}$ MBC processes approaching the cone pedicle. In the closely related carp, dendrites of horseradish peroxidase-injected ON MBCs have been found at similar sites in the cone synaptic complex (Saito et al. 1983, 1985). Lateral elements were unlabeled (Fig. 1d,e, arrows).

Immunolabeling for mGluR $1 \alpha$

Western blotting The mGluR $1 \alpha$ antibody did not recognize any proteins in the goldfish retina, possibly because of the low concentration of the receptor in this tissue. The antibody 
Fig. 1 Ultrastructural localization of protein kinase $\mathrm{C}$ (PKC) in the outer plexiform layer. In the rod spherules $(\mathbf{a}-\mathbf{c})$, invaginating dendrites of putative mixed-input ON-type bipolar cells (ON MBCs) were positively labeled (arrowheads). Lateral elements of horizontal cells ( $\mathrm{HCs}$ ) were unlabeled (arrows), as were some invaginating processes that possibly belonged to OFF-type MBCs (asterisks). In the cone pedicles (d, e), PKC immunoreactivity was observed in small invaginating profiles at the base of the pedicles (arrowheads). These structures were never associated with the synaptic ribbons $(S R)$. HC lateral elements were unlabeled (arrows).

Bars $0.5 \mu \mathrm{m}$
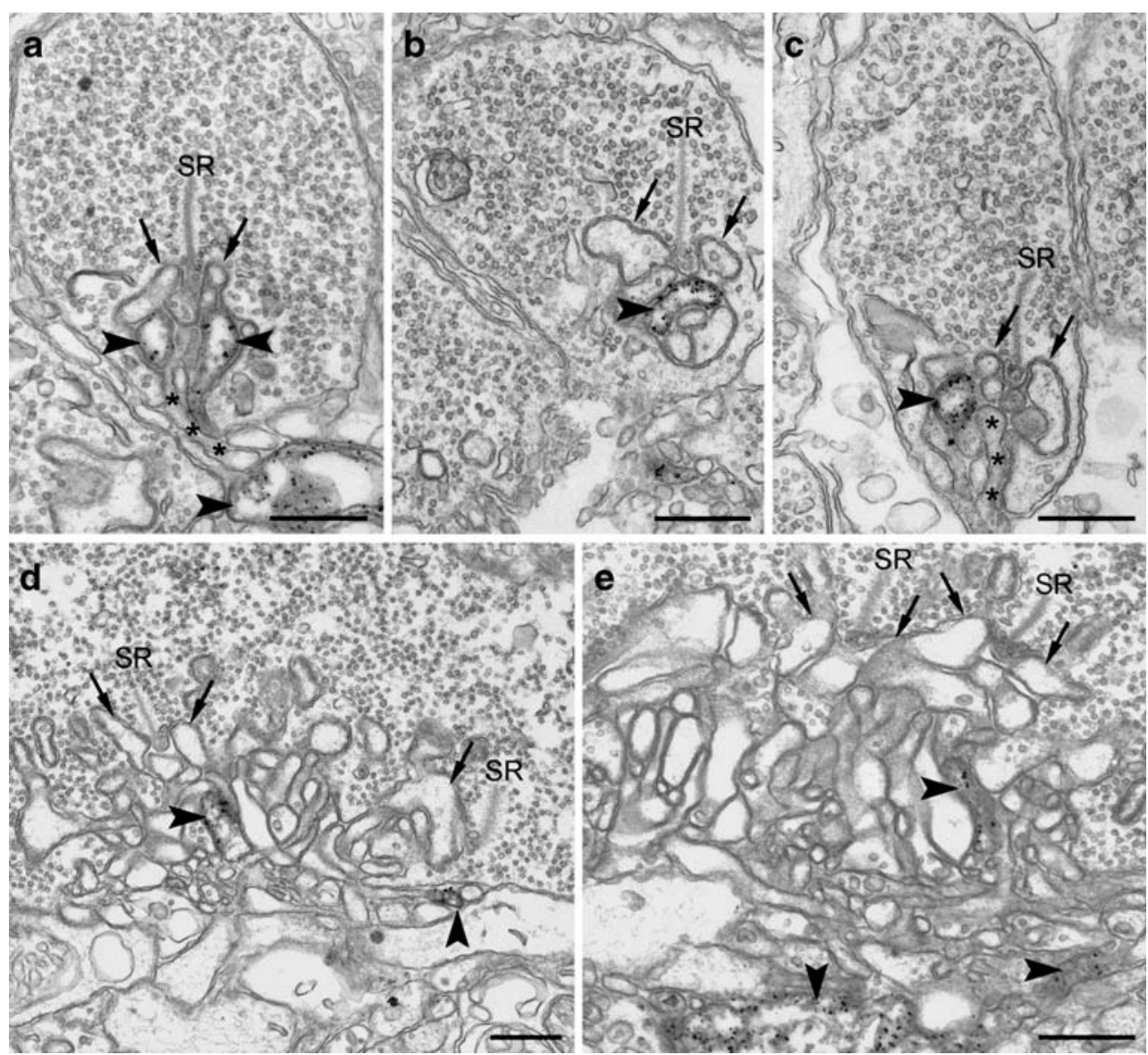

produced a diffuse band at approximately $150 \mathrm{kDa}$ in goldfish brain and rat samples (Fig. 2c), close to the predicted molecular mass of mGluR $1 \alpha$ (Tables 1, 2). The immunoreactive protein found in the rat retina was faint, probably reflecting the restricted expression of this receptor in retinal tissue.

Light microscopy mGluR $1 \alpha$ immunoreactivity in the goldfish retina was concentrated in the OPL (Fig. 2a) and outer half of the INL in which the somata of some bipolar cells were labeled (Fig. 2a, arrowheads). A confocal examination of the immunofluorescence pattern yielded by this antibody revealed diffuse labeling in the INL, inner plexiform layer (IPL), and ganglion cell layer (GCL; Fig. 2d). Red and green images of a confocal view were taken from a retinal slice double-labeled for mGluR $1 \alpha$ (Fig. 2d) and PKC (Fig. 2e); the yellow areas in the merged image (Fig. 2f) indicated the strong colocalization in $\mathrm{ON} B C$ processes in the OPL. However, mGluR $1 \alpha$ immunoreactivity in this layer was not restricted to PKC-positive processes. Furthermore, the small PKC-positive ON BCs were not positive for mGluR $1 \alpha$ (Fig. 2 d,e, asterisks). Conversely, the mGluR $1 \alpha-$ antibody labeled structures (presumably amacrine cell somata) in the inner border of the INL that were not PKC-positive (Fig. 2d,e, circles).
Electron microscopy: rod synapses In the rod spherule, mGluR $1 \alpha$ immunoreactivity was present at invaginating dendrites in close apposition to the synaptic ribbons (Fig. 3a-d, arrowheads). These processes were elongated (Fig. 3a), ellipsoidal (Fig. 3b), goblet-shaped (Fig. 3c), or round (Fig. 3d), consistent with ON MBC dendrites. Roughly two invaginating dendrites were stained per rod spherule; the remaining invaginating dendrites (Fig. 3a,b, asterisks) were not labeled. These were possibly OFF MBCs, rod-driven HCs, or a subtype of ON MBC negative for mGluR $1 \alpha$.

The antibody also labeled single lateral elements facing the synaptic ribbon (Fig. 3d, thick arrow). Whenever a lateral element was labeled, the other one was unlabeled (Fig. 3d, arrow). Although processes in the lateral position are classically attributed as belonging to HCs (Stell 1967, 1976), we could not fully exclude the possibility that some of the labeled processes were aberrant $\mathrm{ON}$ MBC dendrites.

Electron microscopy: cone synapses In the cone pedicles, various types of post-synaptic structures were labeled. In addition to small invaginating processes (Fig. 3e,f, arrowheads), which could belong to BCs, mGluR $1 \alpha$ immunoreactivity was also present at one lateral dendrite of some cone triads (Fig. 3e, thick arrows). The position and fine structure of these dendrites were consistent with those of cone-driven 


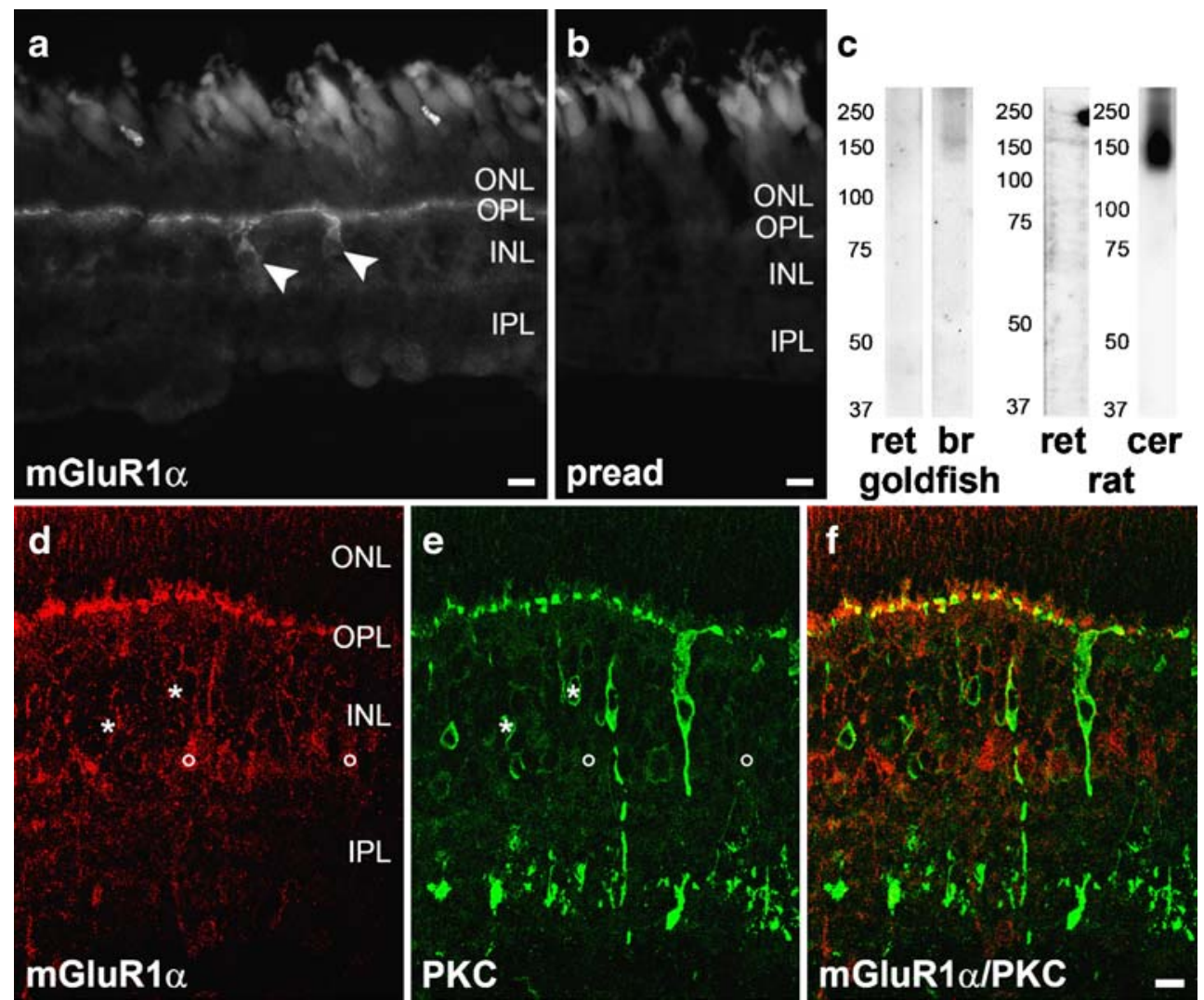

Fig. 2 Immunolabeling for mGluR1 $\alpha(O N L$ outer nuclear layer, $O P L$ outer plexiform layer, $I N L$ inner nuclear layer, $I P L$ inner plexiform layer). a Immunoreactivity was concentrated at the OPL and outer half of the INL in which some BC somata were partially labeled (arrowheads). b Preadsorption with the control peptide (pread) abolished all labeling. c Western blot of total protein from goldfish retina (ret), goldfish brain $(b r)$, rat retina (ret), and rat cerebrum (cer). A protein at around $150 \mathrm{kDa}$, close to the predicted molecular mass of mGluR $1 \alpha$, was detected in goldfish brain, rat retina, and rat cerebrum. d, e Red and

HCs (Stell 1967, 1976; Sakai and Naka 1983). When one lateral $\mathrm{HC}$ dendrite in a triad was positive for $\operatorname{mGluR} 1 \alpha$, the opposite $\mathrm{HC}$ dendrite was not (Fig. 3e, thick and thin arrows, respectively). A few invaginations in the cone pedicle containing discontinuous patches of electron-dense material in the membrane and resembling HC spinules (Wagner 1980) exhibited mGluR1 $\alpha$ immunoreactivity (Fig. 3f, thick arrows).

\section{Immunolabeling for mGluR2/3}

Western blotting The antibody against mGluR2/3 reacted with proteins of approximately $100 \mathrm{kDa}$ in goldfish brain, rat retina, and rat cerebrum (Fig. 4c). This is the predicted molecular mass of mGluR2 and mGluR3 (Tables 1,2). In the goldfish retina, only a protein at about $200 \mathrm{kDa}$ was detected, which also appeared in the other three tissue samples. This probably represents receptor dimers (Poli et al. 1999), which occur naturally in many G-protein-coupled receptors, green channel confocal images of the same tissue section double-labeled with antibodies against mGluR1 $\alpha(\mathrm{Cy} 3, \mathbf{d})$ and PKC (Alexa, e). Some structures were positive for mGluR $1 \alpha$ but not for PKC (circles). Some small BCs were positive for the ON BC marker but not mGluR $1 \alpha$ (asterisks). $\mathbf{f}$ Merged image of the double-labeling experiment. A band of mGluR $1 \alpha$ immunoreactivity in the OPL partially overlapped with the dendritic processes of PKC-positive cells. Areas of overlap between the two proteins appear yellow. Bars $10 \mu \mathrm{m}$

including mGluRs (Bouvier 2001; Kubo and Tateyama 2005; Pin et al. 2005; Poli et al. 2003; Beraudi et al. 2007). In goldfish and rat retinas, a smaller band at around $40 \mathrm{kDa}$ was detected.

Light microscopy Immunocytochemistry with the mGluR2/3 antibody revealed signal in the OPL and INL and strong labeling in the IPL. Tiny discontinuous immunoreactive bands were visible in the OPL (Fig. 4a, thick arrows). Confocal images showed a similar pattern, with a slightly stronger OPL labeling (Fig. 4d, thick arrows). Clearly labeled somata could not be distinguished, although immunolabeling in the INL was concentrated in patches. Immunoreactivity for PKC (Fig. 4e) did not colocalize with mGluR2/3 (Fig. 4d), as can be seen by the absence of yellow areas in the merged confocal image (Fig. 4f).

Electron microscopy: rod synapses No immunoreactive processes could be identified in the rod synaptic terminals. 


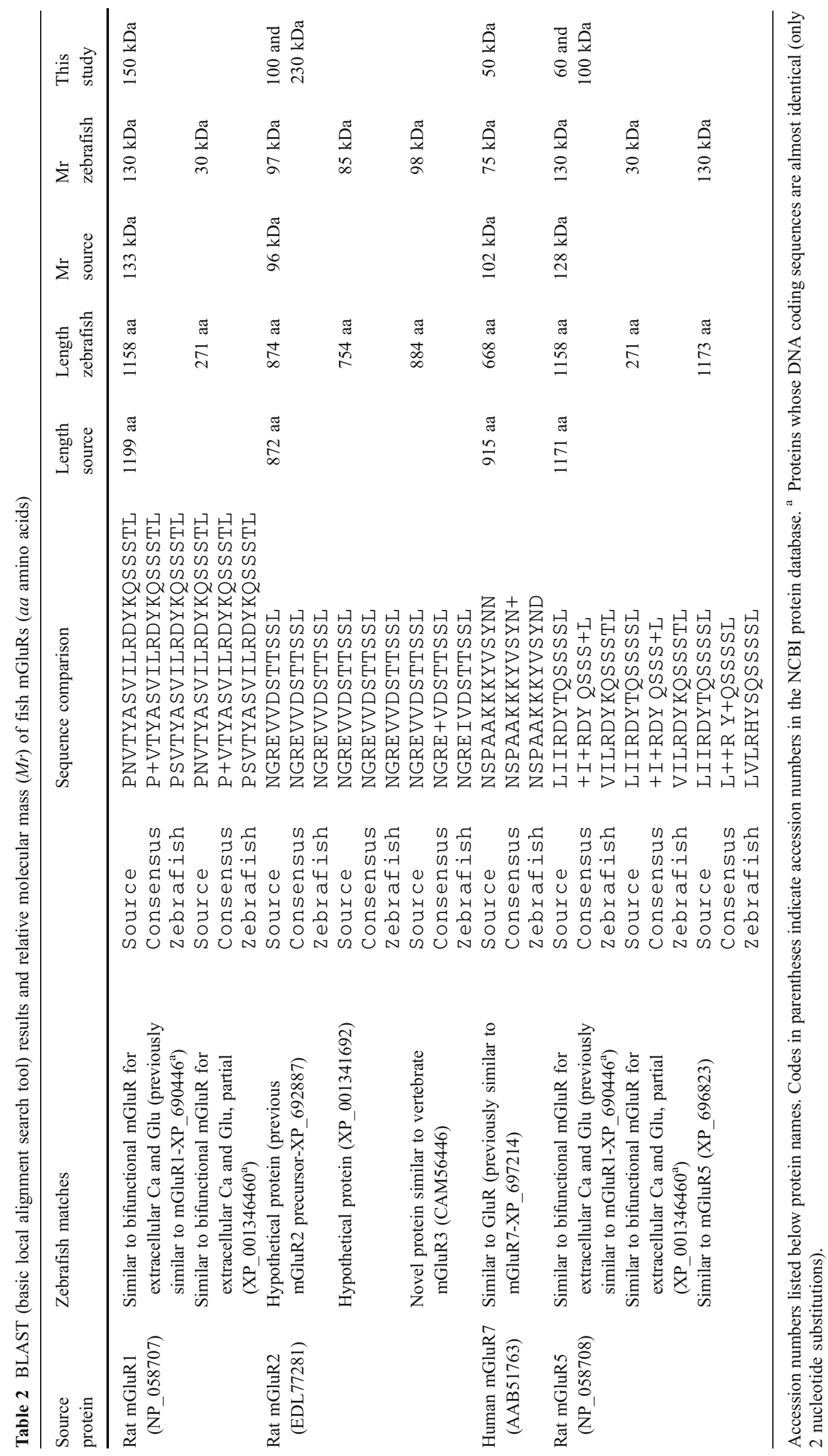


Fig. 3 Ultrastructural localization of mGluR $1 \alpha$ in the OPL. In the rod terminals $(\mathbf{a}-\mathbf{d}), \mathrm{ON}$ $\mathrm{MBC}$ invaginating processes at the summit of the synaptic ribbon $(S R)$ were positively labeled (arrowheads). Some invaginating processes were not labeled (asterisks); these might belong to OFF MBCs, to rod-driven $\mathrm{HCs}$, or to a subtype of ON MBC negative for mGluR $1 \alpha$. Occasionally, a laterally positioned dendrite showed mGluR $1 \alpha$ immunoreactivity (thick arrow in d). In the cone pedicles (e, f), mGluR $1 \alpha$ immunoreactivity was found in small invaginating profiles that lay at the base of the pedicles or close to the ribbon (arrowheads) and that might have originated in BCs. In addition, a $\mathrm{HC}$ dendrite occupying the lateral position of the triads was positively labeled (thick arrows in $\mathbf{e}$ ), whereas the other lateral element was unlabeled (arrows). The antibody also labeled $\mathrm{HC}$ spinules in the cone terminals (thick arrows in f). Bar $0.25 \mu \mathrm{m}$
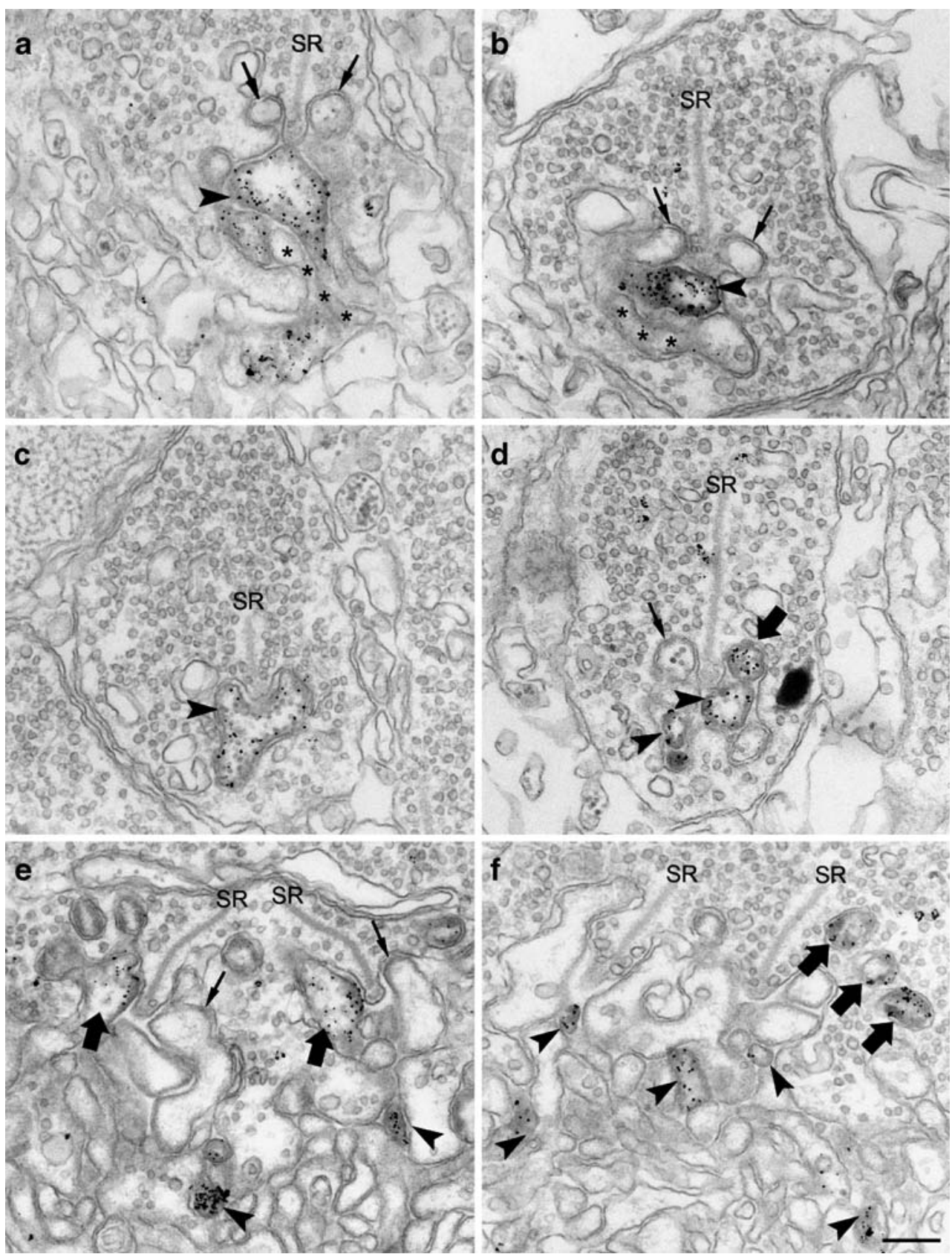

Electron microscopy: cone synapses HC dendrites occupying both the lateral and central position were positive for mGluR2/3 in only a few cone pedicles (Fig. $4 \mathrm{~g}-\mathrm{h}$, thick arrows). The fine structure of the central processes was consistent with that of $\mathrm{HC}$ dendrites because of their large dimensions compared with $\mathrm{BC}$ dendrites, cytoplasm devoid of organelles, some electron-dense amorphous material applied to the cytoplasmic surface, and concavity of the surface facing the synaptic ribbon (Stell 1967, 1976; Scholes 1975). No mGluR2/3 immunoreactivity was seen in structures resembling $\mathrm{BC}$ dendrites, in agreement with our light-microscopical findings.
Immunolabeling for mGluR5

Western blotting Immunoblots for mGluR5 revealed a protein at around $100 \mathrm{kDa}$ in goldfish retina and brain and in rat cerebrum (Fig. 5c). An additional band at $60 \mathrm{kDa}$ was detected in the goldfish samples and in the rat retina. A heavier protein of around $145 \mathrm{kDa}$ was detected in rat retina and cerebrum, roughly corresponding to the deduced molecular mass of rat mGluR5 (Koulen et al. 1997).

Light microscopy The mGluR5 antibody labeled vertical bands at the outer nuclear layer (ONL) in both conventional 
Fig. 4 Immunolabeling for mGluR2/3 (ONL outer nuclear layer, $O P L$ outer plexiform layer, $I N L$ inner nuclear layer, $I P L$ inner plexiform layer). a Immunoreactivity was seen as tiny bands in the OPL (thick arrows), irregular patches in the INL, and diffuse labeling in the IPL. b Preadsorption with the control peptide (pread) abolished all labeling. c Western blot of total protein from goldfish retina (ret), goldfish brain $(b r)$, rat retina (ret), and rat cerebrum (cer). A protein at around $100 \mathrm{kDa}$, close to the predicted molecular mass of mGluR2 and mGluR3, was detected in goldfish brain, rat retina, and rat cerebrum. The antibody also detected a protein at $200 \mathrm{kDa}$ (probably receptor dimers) in all four tissues. $\mathbf{d}$, e Red and green channel confocal images of the same tissue section double-labeled with antibodies against mGluR $2 / 3$ $(\mathrm{Cy} 3, \mathbf{d})$ and PKC (Alexa, e). f Merged image of the doublelabeling experiment. No colocalization with ON BCs was found. Bars $10 \mu \mathrm{m} . \mathbf{g}$, $\mathbf{h}$ In a few cone pedicles, mGluR2/3 immunoreactivity was found in $\mathrm{HC}$ central and lateral elements of the cone triad (thick arrows). Note the unlabeled lateral processes (thin arrows) and synaptic ribbons $(S R)$. Bars $0.5 \mu \mathrm{m}$
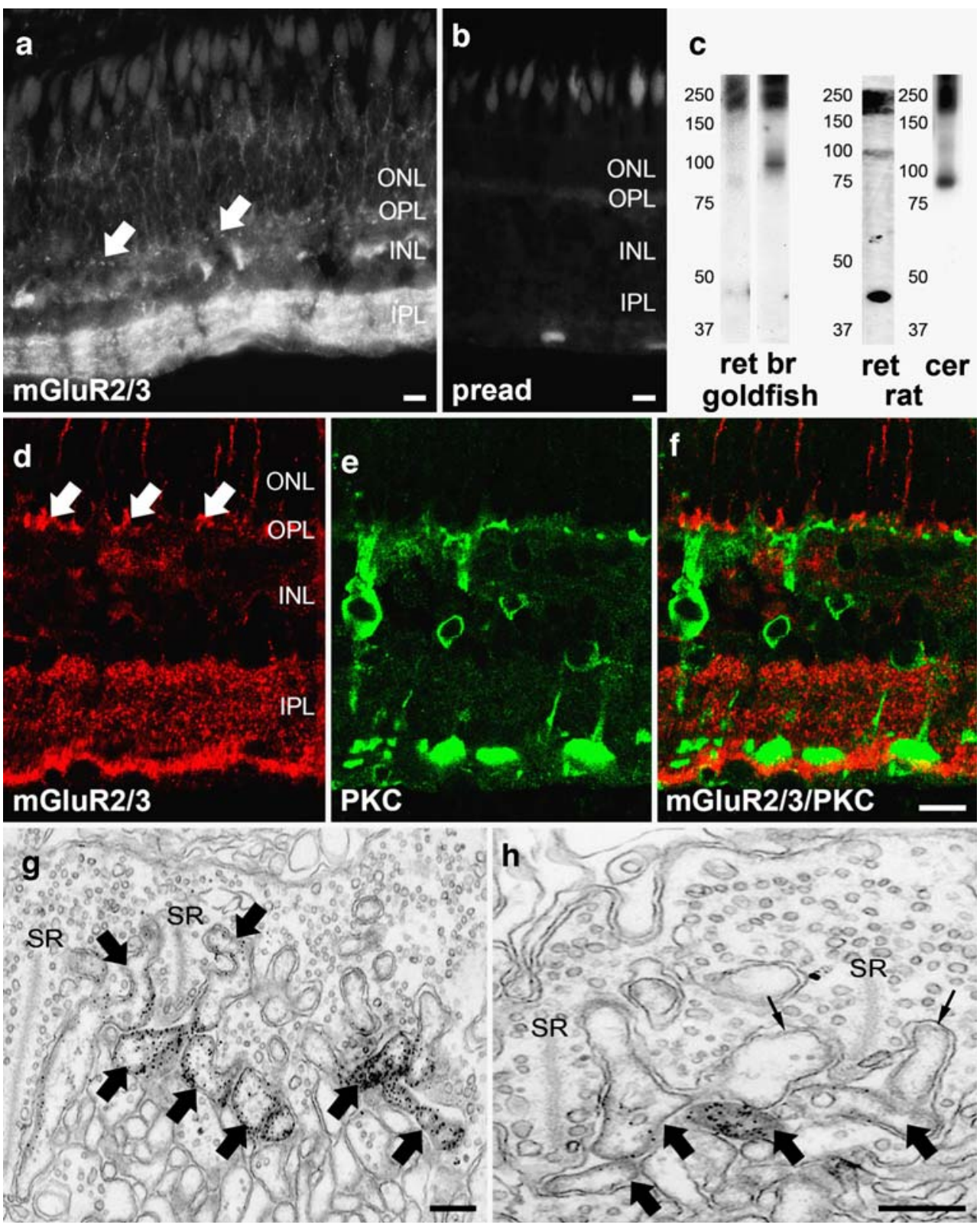

(Fig. 5a, open arrows) and confocal microscopy (Fig. 5d, open arrows) and yielded granular labeling in the OPL, INL, and IPL. Some HC somata were positively labeled at the outer margin of the INL (Fig. 5a,d, thick arrows). There was no colocalization with PKC (Fig. 5d-f).

Electron microscopy Ultrastructurally, mGluR5 immunoreactivity was seen in longitudinally oriented structures between photoreceptor terminals (Fig. 5g, open arrows). This pattern was consistent with previous reports concerning the localization and ultrastructural appearance of Müller cell processes (Villegas 1960; Lasansky 1961; Pedler 1963; Miller and Dowling 1970). Furthermore, it resembled closely that of immunolabeling for glial fibrilary acidic protein (Fig. 5h, open arrows), which is exclusively expressed by glial cells (Bignami and Dahl 1977; Liepe et al. 1994).

Immunolabeling for mGluR7

Western blotting A protein of approximately $50 \mathrm{kDa}$ was labeled in goldfish and rat samples, with an additional band of around $75 \mathrm{kDa}$ in the goldfish brain. In the rat retina, a protein of $200 \mathrm{kDa}$ was also recognized. A clear band could not be distinguished in rat cerebrum, although there was a larger precipitation around $50 \mathrm{kDa}$ (Fig. 6c), at some distance from the value reported by the producer (Table 1).

Light microscopy The antibody against mGluR7 immunoreactivity yielded strong labeling in the OPL (Fig. 6a, 
Fig. 5 Immunolabeling for mGluR5 (ONL outer nuclear layer, $O P L$ outer plexiform layer, $I N L$ inner nuclear layer, IPL inner plexiform layer). a Immunoreactivity was concentrated in the ONL (open arrows), with some granular labeling in the OPL, INL, and IPL (thick arrow labeled HC body). b Preadsorption with the control peptide (pread) abolished all labeling. c Western blot of total protein from goldfish retina (ret), goldfish brain $(b r)$, rat retina (ret), and rat cerebrum (cer). A protein around $100 \mathrm{kDa}$ was detected in the goldfish tissue and rat brain. The antibody also a smaller band $(60 \mathrm{kDa})$ in the goldfish samples and in the rat retina, and a heavier band $(145 \mathrm{kDa})$ in the rat retina and cerebrum. d, e Red and green channel confocal images of the same tissue section double-labeled with antibodies against mGluR5 $(\mathrm{Cy} 3, \mathbf{d})$ and PKC (Alexa, e). f Merged image of the double-labeling experiment, showing no colocalization. Bars $10 \mu \mathrm{m}$. g Labeling is restricted to processes ensheathing photoreceptor terminals in the ONL (open arrows). $\mathbf{h}$ A similar labeling pattern (open arrows) is obtained with the monoclonal antibody against glial fibrilary acidic protein (GFAP; clone GA-5, Sigma-Aldrich; 1:400), which labels exclusively Müller cells ( $S R$ synaptic ribbon). Bars $0.5 \mu \mathrm{m}$


arrowheads) and granular labeling at the INL, IPL, and GCL. Occasionally, positive amacrine and ganglion cell somata were seen. Confocal images of double-labeling with PKC (Fig. 6d-f) did not show colocalization: mGluR7positive areas were concentrated close to the outer border of the INL, immediately below the band of PKC-positive ON BC dendrites. Some mGluR7-positive somata that were not labeled for PKC could be identified in the outer half of the INL; their form and position was consistent with that of HCs (Fig. 6d,e, thick arrow) and OFF BCs (Fig. 6d,e, arrowhead).

Electron microscopy: rod synapses Lateral elements of the rod triads were labeled, consistent with the labeling of putative HCs reported above (Fig. 6g, thick arrows). We found no evidence of MBC labeling in rod spherules.

Electron microscopy: cone synapses A few small processes away from the ribbons were labeled by the mGluR7 antibody (Fig. 6h, arrowheads). Their small profiles resembled those of BCs. This observation, added to the finding that the antibody labeled PKC-negative BC somata (Fig. 6d,e, arrow), suggested that these were OFF BC profiles. Lateral elements (Fig. 6h, thick arrow) and spinules were also labeled, consistent with HC labeling at the light-microscopical level (Fig. 6d, $\mathrm{e}$, thick arrows). These labeled HC processes were however rare; most of the lateral elements were not positive (Fig. 6h, thin arrows). 
Fig. 6 Immunolabeling for mGluR7 (ONL outer nuclear layer, $O P L$ outer plexiform layer, $I N L$ inner nuclear layer, IPL inner plexiform layer). a Immunoreactivity was concentrated in the OPL (arrowheads), with some granular labeling in the INL, IPL, and GCL.

b Preadsorption with the control peptide (pread) abolished all labeling. c Western blot of total protein from goldfish retina (ret), goldfish brain $(b r)$, rat retina (ret), and rat cerebrum (cer). A pronounced band at around $50 \mathrm{kDa}$ was produced in all four samples. Additional immunoreactive proteins were found at $75 \mathrm{kDa}$ in the goldfish tissue and at $200 \mathrm{kDa}$ in the rat retina. $\mathbf{d}$, $\mathbf{e}$ Red and green channel confocal images of the same tissue section double-labeled with antibodies against mGluR7 $(\mathrm{Cy} 3, \mathbf{d})$ and PKC (Alexa, e). A BC soma (arrowheads) and an HC soma (thick arrows) were positive for mGluR7 but negative for PKC. f Merged image of the doublelabeling experiment, showing no colocalization in ON BCs. $\mathbf{g}$ In rod spherules, lateral elements were labeled (thick arrows). $\mathbf{h}$ In the cone pedicles, small profiles not related to the synaptic ribbons (SR) were positive (arrowheads), as were lateral elements of the triads (thick arrow). Note the unlabeled lateral elements (thin arrows). Bars $0.25 \mu \mathrm{m}$
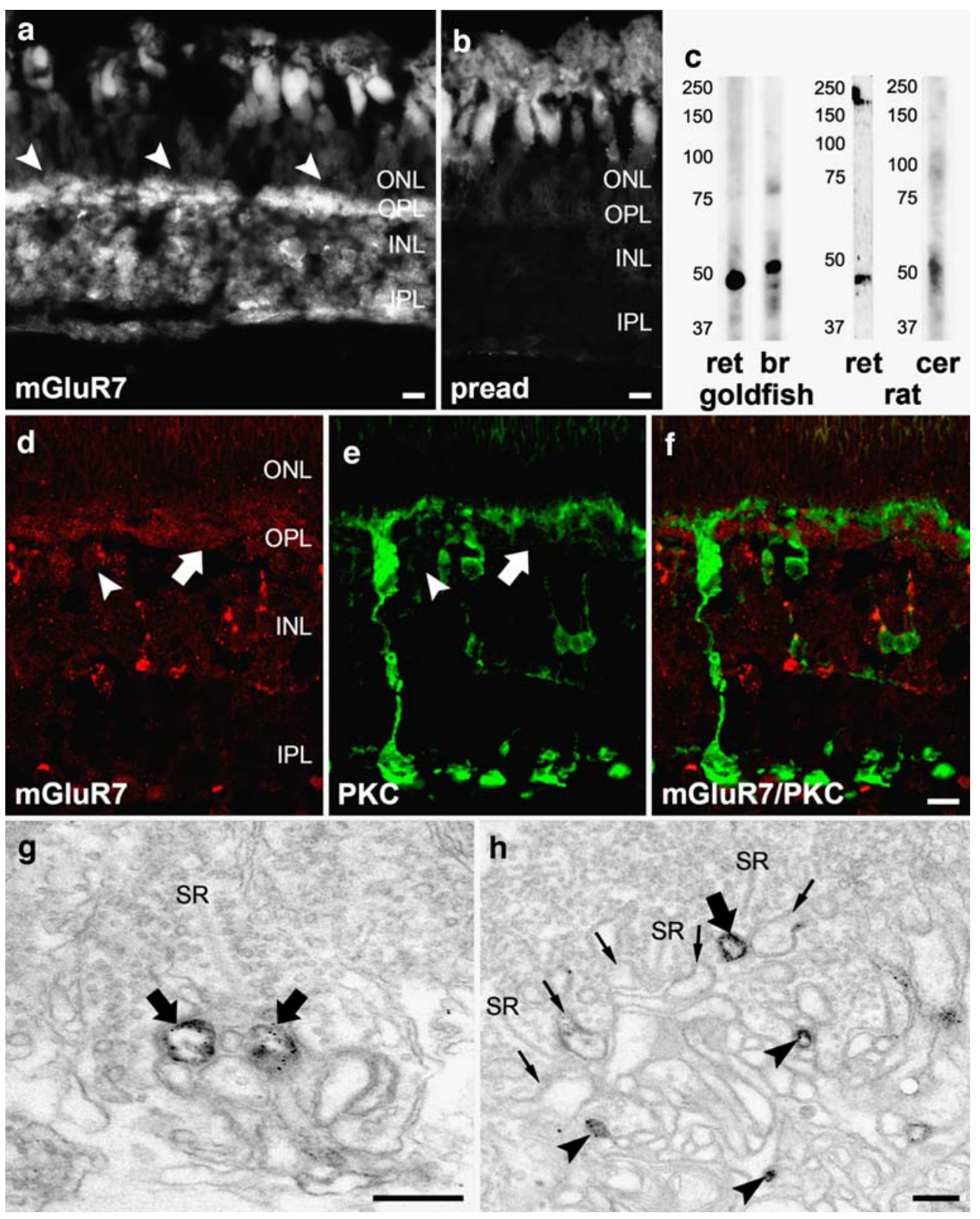

\section{Discussion}

Summarizing scheme

This study shows that mGluRs of all three groups can be found in the goldfish OPL. The main findings are summarized in Fig. 7. Cell types have been identified based on the results obtained at both light-microscopy and electron-microscopy levels.

In the rod spherule, PKC labels invaginating dendrites of putative ON MBCs. The mGluR $1 \alpha$ antibody labels similar structures and some lateral elements. Lateral elements of rod triads are also positive for mGluR7. Müller cell processes between the rod spherules are positive for mGluR5. We have found no evidence for mGluR2/3 in the rod synaptic complex.
In the cone pedicles, PKC labels fine dendrites at the base of the terminal or invaginating structures away from the ribbons. Elements at similar positions and with similar fine structure are positive for mGluR $1 \alpha$ and mGluR7. BC central processes in the cone triads are positive for $m G l u R 1 \alpha$. Spinules are positive for mGluR $1 \alpha$ and mGluR7, and lateral elements are labeled by the mGluR $1 \alpha$, GluR2/3, and mGluR7 antibodies. Finally, $\mathrm{HC}$ central elements are positive for mGluR2/3.

Specificity of the antibodies

No data are available on the amino acid and/or nucleotide sequences of goldfish mGluRs. The closest available information is from the zebrafish. This database is however not fully completed, and the various zebrafish mGluRs have not been 
Fig. 7 Representation of a rod spherule, a Müller cell process, and a cone pedicle, depicting the localization of PKC and the patterns yielded by the various mGluR antibodies (red group I mGluRs, green group II mGluRs, blue group III mGluRs, $S R$ synaptic ribbon)

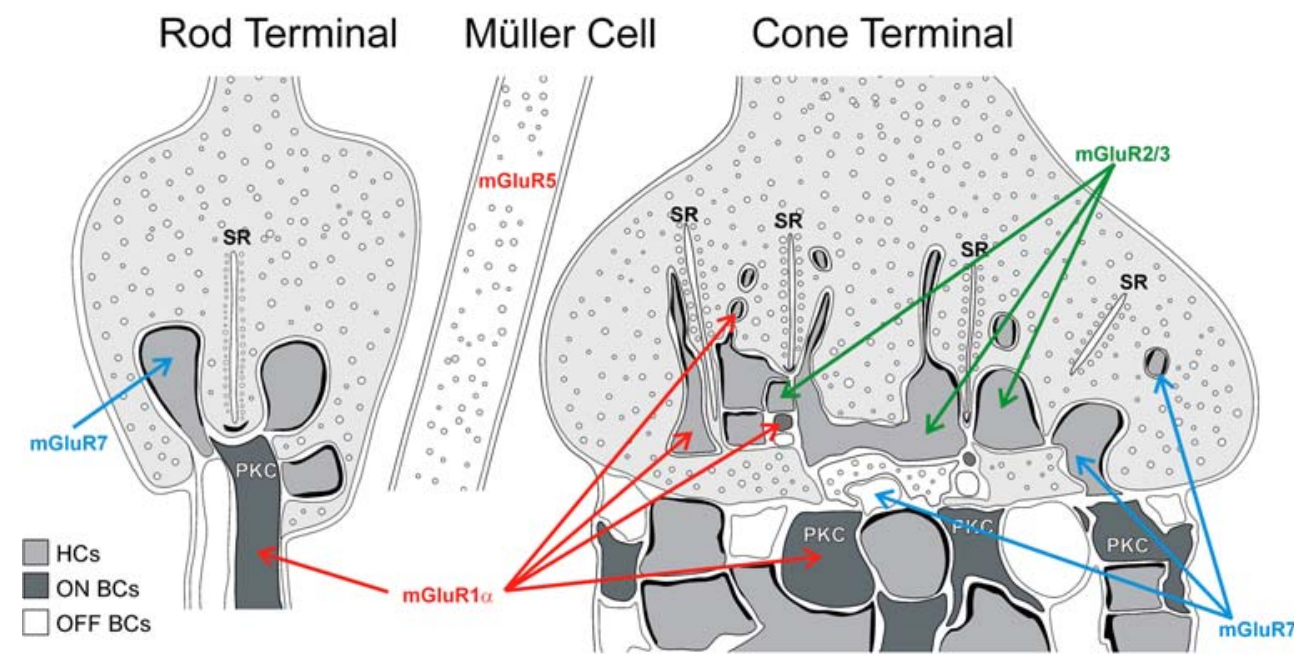

unambiguously identified (Table 2). The finding of candidates for zebrafish mGluR2 and mGluR6 has been reported, but the actual nucleotide and amino acid sequences have not been disclosed (Bjarnadottir et al. 2005).

We therefore used multiple data sources to infer the specificity of the antibodies used in this study: Western blots and BLAST searches in the zebrafish genome for the amino acid sequences in Table 1 (at http://www.ncbi.nlm.nih.gov/ BLAST/), the sequence alignments (with http://www.ch. embnet.org/software/LALIGN_form.html and http://bioinfo. genopole-toulouse.prd.fr/multalin/multalin.html), and the molecular mass calculations (at http:/www.basic.northwestern. edu/biotools/proteincalc.html). We also "BLASTed" the proteins retrieved from the zebrafish database against all other species available, in order to check for protein similarities among species.

To choose good candidates for fish mGluRs among the BLAST hits, we relied on the scores and E-values; the cutoff was $\mathrm{E}<0.01$. We adopted a stringent significance level, because the chance of obtaining random matches with short amino acid sequences was relatively large. All scores used for these comparisons were higher than 1,000. For the C-terminal mGluR5 peptide, the cutoff was lowered to $E=0.35$, since no candidates could be found with the same stringency as for the remainder of the peptide sequences.

As summarized in Table 2, all of the anti-mGluR antibodies used in this study were raised against polypeptides that yielded mGluR-like hits when "BLASTed" against the zebrafish database. Two homologs were found for mGluR1, but one of these (XP_001346460) was an incomplete sequence that might have corresponded to a fragment of the other (XP_690446), since they only differed by one amino acid and their respective coding sequences by two nucleotides. For mGluR2/3, three putative mGluRs were identified (Table 2), but one of them had a slightly smaller molecular mass than the other two $(85 \mathrm{kDa})$. We did not however detect multiple proteins around $80-100 \mathrm{kDa}$ in our immunoblots, which suggested that XP_001341692 was not present in the goldfish retina.

According to the database search, the C-terminal peptides of mGluR5 and mGluR7 have one fish homolog each. The mGluR5 candidate shows lowest amino acid sequence similarity at the $\mathrm{C}$-terminus, but the lack of overlapping expression patterns between mGluR1 and mGluR5 in the OPL of the goldfish retina excludes cross-reactivity of anti-mGluR5 and mGluR1.

In summary, we feel confident about the specificity of the commercially available anti-mGluR peptide antibodies, since the carboxytermini of mammalian and fish mGluR homologs are nearly identical, and the molecular masses of fish and mammalian homologs are similar (Table 2).

mGluRs of Müller cells

The finding of mGluR5 in Müller cells is in agreement with two previous studies of isolated Müller cells from the salamander; these studies have shown that activation of group I mGluRs has two major effects. First, it leads to the closure of the $\mathrm{K}^{+}$conductance of these cells, which is by far the largest in Müller cells (Schwartz 1993). Since their glutamate uptake is both voltage-dependent (Brew and Attwell 1987; Schwartz and Tachibana 1990) and regulated by the internal $\mathrm{K}^{+}$ concentration (Barbour et al. 1988), one can imagine that mGluR5, by modulating this $\mathrm{K}^{+}$conductance, indirectly modulates glutamate uptake by changing the membrane potential and/or internal $\mathrm{K}^{+}$concentration.

The second effect of group I mGluR activation in Müller cells is the generation of $\mathrm{Ca}^{2+}$ waves by triggering the release of $\mathrm{Ca}^{2+}$ from internal stores (Keirstead and Miller 1997). The physiological consequences of this effect are not completely clear, but they could contribute to lateral signaling among Müller cells, as in astrocytes (Kim et al. 1994). 


\section{mGluRs of HCs}

Here, we show that rod and cone-driven HCs of the goldfish express mGluRs from all three groups, although the exact mGluR composition of these cells differs slightly from reports in other species (i.e., no mGluR1 in cat HCs: Cai and Pourcho 1999; no mGluR2/3 in catfish HCs: Gafka et al. 1999).

We have found that lateral elements in the rod triads are positively labeled for mGluR $1 \alpha$ and mGluR7. Since the labeling for $\operatorname{mGluR} 1 \alpha$ is rare, we cannot at this point positively identify these processes as belonging to either rod-driven HCs or MBCs. In the cone pedicle, mGluRs seem to be expressed in a highly organized manner. mGluR $1 \alpha$ and mGluR7 tend to be localized to spinules and to dendrites occupying the lateral position in the cone triad, whereas mGluR2/3 has been found at both lateral and central processes directly opposing the synaptic ribbon.

This extremely ordered pattern indicates that either a single cone-driven HC type expresses distinct mGluRs in different dendrites, or that the expression of a given mGluR is restricted to a certain subpopulation of HCs (i.e., the distribution is celltype-specific). In cyprinid retinae, three physiological and morphological HC types have been described (MacNichol and Svaetichin 1958; Norton et al. 1968; Stell et al. 1982); one could easily imagine that each $\mathrm{HC}$ class expresses only one or two mGluRs at their dendritic tips.

The light responses of HCs are mediated by AMPA (2amino-4-phosphonobutyric acid)/kainic acid receptors (Lasater and Dowling 1982; Slaughter and Miller 1983; Zhou et al. 1993) and are not abolished by mGluR agonists or antagonists (Yang and Wu 1989; Luo and Liang 2003), showing that mGluRs are not implicated in the direct generation of light responses. They are most likely involved in the modulation of the light-driven conductance of these cells. In the fish retina, for instance, mGluR agonists have been shown to modify both light-modulated (Nawy et al. 1989; Yasui et al. 1990; Takahashi and Copenhagen 1992) and voltage-gated conductances of cone-driven HCs (Dixon and Copenhagen 1997; Linn and Gafka 1999; Gafka et al. 1999).

\section{mGluRs of ON MBCs}

The labeling of ON MBC processes, in the rod spherule, with the antibody against mGluR $1 \alpha$ corroborates previous studies in fish (Klooster et al. 2001; Yazulla and Studholme 2001; Yazulla et al. 2001) and mammalian (Koulen et al. 1997) species, although it differs from the situation in the cat retina, in which $\mathrm{mGluR} 1 \alpha$ is pre-synaptic to rod-driven BCs (Cai and Pourcho 1999). Since no evidence has as yet been presented for the participation of group I mGluRs in the generation of the light responses of $\mathrm{ON} \mathrm{BCs}$, one can only speculate that this protein plays a modulatory role in the first synapse. In many parts of the central nervous system, group I mGluRs are involved in controlling the intracellular calcium concentration and membrane channel activity (for a review, see Fagni et al. 2000). In the spinal cord neurons of the lamprey, for instance, mGluR1 has been shown to regulate the resting membrane potential and thus the excitability of the cells by controlling a leak current (Kettunen et al. 2003).

Although there is physiological evidence for the existence of a group III mGluR in fish ON MBCs (Shiells et al. 1981; Nawy and Copenhagen 1987; Kamermans et al. 2004), we have not been successful in obtaining specific immunoreactivity with the antibodies commercially available against (mammalian) mGluR4, mGluR6, and mGluR8. Furthermore, there is as yet no candidate for mGluR6 in the zebrafish database, which makes the production of custom-made antibodies against this protein difficult. One would however expect these cells to express an mGluR6-like receptor, given the many physiological similarities between the rod-driven conductance in fish and mammalian ON BCs.

Whether and in what manner this mGluR6-like receptor and the $\mathrm{mGluR} 1 \alpha$-like protein interact in ON MBCs is still to be resolved. G-protein-coupled receptors can interact at many levels. For instance, gamma-aminobutyric $\operatorname{acid}_{B}$ receptors form complexes with $\mathrm{mGluR} 1 \alpha$ dimers and thereby regulate the sensitivity of the latter to glutamate (for a review, see Kubo and Tateyama 2005). Interactions between mGluRs, however, have so far not been described. Another level of interaction lies within the second-messenger cascade. Until recently, only one G-protein $\left(\mathrm{G}_{\mathrm{o}} \alpha\right)$ had been described in ON BCs (Vardi et al. 1993), which suggests that mGluR $1 \alpha$ and mGluR6 share (part of) the same intracellular machinery. Nonetheless, a second G-protein $\left(G_{i} 2 \alpha\right)$ has been shown to coexist with $G_{o} \alpha$ in rat ON BCs and not to couple to mGluR6 (Tian and Kammermeier 2006), providing an independent G-protein signaling pathway within these cells; this pathway might involve mGluR $1 \alpha$.

Acknowledgements The authors thank Dr. Willem Kamphuis for valuable comments on early versions of this manuscript, Dr. Robert Duvoisin for providing samples of the anti-mGluR7 antibody, Dr. Bob Nunes-Cardozo for the confocal pictures, and Ton Put for preparing the figures.

\section{References}

Abe T, Sugihara H, Nawa H, Shigemoto R, Mizuno N, Nakanishi S (1992) Molecular characterization of a novel metabotropic glutamate receptor mGluR5 coupled to inositol phosphate/Ca ${ }^{2+}$ signal transduction. J Biol Chem 267:13361-13368

Akazawa C, Ohishi H, Nakajima Y, Okamoto N, Shigemoto R, Nakanishi S, Mizuno N (1994) Expression of mRNAs of 1-AP4sensitive metabotropic glutamate receptors (mGluR4, mGluR6, mGluR7) in rat retina. Neurosci Lett 171:52-54 
Barbour B, Brew H, Attwell D (1988) Electrogenic glutamate uptake in glial cells is activated by intracellular potassium. Nature 355:433435

Beraudi A, Bruno V, Battaglia G, Biagioni F, Rampello L, Nicoletti F, Poli A (2007) Pharmacological activation of mGlu2/3 metabotropic glutamate receptors protects retinal neurons against anoxic damage in the goldfish Carassius auratus. Exp Eye Res 84:544552

Bignami A, Dahl D (1977) Specificity of the glial fibrillary acidic protein for astroglia. J Histochem Cytochem 25:466-469

Bjarnadottir TK, Fredriksson R, Schioth HB (2005) The gene repertoire and the common evolutionary history of glutamate, pheromone (V2R), taste(1) and other related G protein-coupled receptors. Gene 362:70-84

Bouvier M (2001) Oligomerization of G-protein-coupled transmitter receptors. Nat Rev Neurosci 2:274-286

Brew H, Attwell D (1987) Electrogenic glutamate uptake is a major current carrier in the membrane of axolotl retinal glial cells. Nature 327:707-709

Cai W, Pourcho RG (1999) Localization of metabotropic glutamate receptors mGluR1alpha and mGluR $2 / 3$ in the cat retina. J Comp Neurol 407:427-437

Cervetto L, MacNichol EF (1972) Inactivation of horizontal cells in turtle retina by glutamate and aspartate. Science 178:767-768

Dixon DB, Copenhagen DR (1997) Metabotropic glutamate receptormediated suppression of an inward rectifier current is linked via a cGMP cascade. J Neurosci 17:8945-8954

Duvoisin RM, Zhang C, Ramonell K (1995) A novel metabotropic glutamate receptor expressed in the retina and olfactory bulb. J Neurosci 15:3075-3083

Eccles JC, McGeer PL (1979) Ionotropic and metabotropic neurotransmission. Trends Neurosci 2:39-40

Fagni L, Chavis P, Ango F, Bockaert J (2000) Complex interactions between mGluRs, intracellular $\mathrm{Ca}^{2+}$ stores and ion channels in neurons. Trends Neurosci 23:80-88

Gafka AC, Vogel KS, Linn CL (1999) Evidence of metabotropic glutamate receptor subtypes found on catfish horizontal and bipolar retinal neurons. Neuroscience 90:1403-1414

Gorcs TJ, Leranth C, MacLusky NJ (1986) The use of gold-substituted silver-intensified diaminobenzidine (DAB) and non-intensified $\mathrm{DAB}$ for simultaneous electron microscopic immunoperoxidase labeling of tyrosine hydroxylase and glutamic acid decarboxylase immunoreactivity in the rat medial preoptic area. J Histochem Cytochem 34:1439-1447

Hirasawa H, Shiells R, Yamada M (2002) A metabotropic glutamate receptor regulates transmitter release from cone presynaptic terminals in carp retinal slices. J Gen Physiol 119:55-68

Hosoi N, Arai I, Tachibana M (2005) Group III metabotropic glutamate receptors and exocytosed protons inhibit L-type calcium currents in cones but not in rods. J Neurosci 25:4062-4072

Houamed KM, Kuijper JL, Gilbert TL, Haldeman BA, O'Hara PJ, Mulvihill ER, Almers W, Hagen FS (1991) Cloning, expression, and gene structure of a $\mathrm{G}$ protein-coupled glutamate receptor from rat brain. Science 252:1318-1321

Kamermans M, Joselevitch C, Klooster J (2004) Rod-driven lightresponses in mixed-input bipolar cells. ARVO Abstracts 45:EAbstract 2198

Kaneko A, Shimazaki H (1976) Synaptic transmission from photoreceptors to bipolar and horizontal cells in the carp retina. Cold Spring Harb Symp Quant Biol 40:537-546

Keirstead SA, Miller RF (1997) Metabotropic glutamate receptor agonists evoke calcium waves in isolated Muller cells. Glia 21: 194-203

Kettunen P, Hess D, El Manira A (2003) mGluR1, but not mGluR5, mediates depolarization of spinal cord neurons by blocking a leak current. J Neurophysiol 90:2341-2348
Kim WT, Rioult MG, Cornell-Bell AH (1994) Glutamate-induced calcium signaling in astrocytes. Glia 11:173-184

Klooster J, Studholme KM, Yazulla S (2001) Localization of the AMPA subunit GluR2 in the outer plexiform layer of goldfish retina. J Comp Neurol 441:155-167

Koulen P, Kuhn R, Wässle H, Brandstätter JH (1997) Group I metabotropic glutamate receptors mGluR1alpha and mGluR5a: localization in both synaptic layers of the rat retina. J Neurosci 17:2200-2211

Koulen P, Kuhn R, Wässle H, Brandstätter JH (1999) Modulation of the intracellular calcium concentration in photoreceptor terminals by a presynaptic metabotropic glutamate receptor. Proc Natl Acad Sci USA 96:9909-9914

Kubo Y, Tateyama M (2005) Towards a view of functioning dimeric metabotropic receptors. Curr Opin Neurobiol 15:289-295

Lasansky A (1961) Morphological bases for a nursing role of glia in the toad retina. Electron microscope observations. J Biophys Biochem Cytol 11:237-243

Lasater EM, Dowling JE (1982) Carp horizontal cells in culture respond selectively to L-glutamate and its agonists. Proc Natl Acad Sci USA 79:936-940

Laurie DJ, Schoeffter P, Wiederhold KH, Sommer B (1997) Cloning, distribution and functional expression of the human mGlu6 metabotropic glutamate receptor. Neuropharmacology 36:145-152

Liepe BA, Stone C, Koistinaho J, Copenhagen DR (1994) Nitric oxide synthase in Muller cells and neurons of salamander and fish retina. J Neurosci 14:7641-7654

Linn CL, Gafka AC (1999) Activation of metabotropic glutamate receptors modulates the voltage-gated sustained calcium current in a teleost horizontal cell. J Neurophysiol 81:425-434

Luo FJ, Liang PJ (2003) Metabotropic glutamate receptor-mediated hetero-synaptic interaction of red- and green-cone inputs to LHC of carp retina. Brain Res Bull 60:67-71

MacNichol EF, Svaetichin G (1958) Electric responses from the isolated retinas of fishes. Am J Ophthalmol 46:26-46

Masu M, Iwakabe H, Tagawa Y, Miyoshi T, Yamashita M, Fukuda Y, Sasaki H, Hiroi K, Nakamura Y, Shigemoto R (1995) Specific deficit of the ON response in visual transmission by targeted disruption of the mGluR6 gene. Cell 80:757-765

Masu M, Tanabe Y, Tsuchida K, Shigemoto R, Nakanishi S (1991) Sequence and expression of a metabotropic glutamate receptor. Nature 349:760-765

Miller RF, Dowling JE (1970) Intracellular responses of the Muller (glial) cells of mudpuppy retina: their relation to b-wave of the electroretinogram. J Neurophysiol 33:323-341

Murakami M, Ohtsu K, Ohtsuka T (1972) Effects of chemicals on receptors and horizontal cells in the retina. J Physiol (Lond) 227:899-913

Nakajima Y, Iwakabe H, Akazawa C, Nawa H, Shigemoto R, Mizuno N, Nakanishi S (1993) Molecular characterization of a novel retinal metabotropic glutamate receptor mGlur6 with a high agonist selectivity for 1-2-amino-4-phosphonobutyrate. J Biol Chem 268:11868-11873

Nawy S, Copenhagen DR (1987) Multiple classes of glutamate receptor on depolarizing bipolar cells in retina. Nature 325:56-58

Nawy S, Sie A, Copenhagen DR (1989) The glutamate analog 2amino-4-phosphonobutyrate antagonizes synaptic transmission from cones to horizontal cells in the goldfish retina. Proc Natl Acad Sci USA 86:1726-1730

Negishi K, Kato S, Teranishi T (1988) Dopamine cells and rod bipolar cells contain protein kinase C-like immunoreactivity in some vertebrate retinas. Neurosci Lett 94:247-252

Norton AL, Spekreijse H, Wolbarsht ML, Wagner HG (1968) Receptive field organization of the S-potential. Science 160:1021-1022

Okamoto N, Hori S, Akazawa C, Hayashi Y, Shigemoto R, Mizuno N, Nakanishi S (1994) Molecular characterization of a new 
metabotropic glutamate receptor mGluR7 coupled to inhibitory cyclic AMP signal transduction. J Biol Chem 269:1231-1236

Parker PJ, Stabel S, Waterfield MD (1984) Purification to homogeneity of protein kinase $\mathrm{C}$ from bovine brain-identity with the phorbol ester receptor. EMBO J 3:953-959

Pedler C (1963) The fine structure of the radial fibres in the reptile retina. Exp Eye Res 44:296-303

Pin JP, Kniazeff J, Liu J, Binet V, Goudet C, Rondard P, Prezeau L (2005) Allosteric functioning of dimeric class C G-protein-coupled receptors. FEBS J 272:2947-2955

Poli A, Lucchi R, Storto M, De Paolis P, Notari S, Nicoletti F, Casabona G (1999) Predominant expression of group-II metabotropic glutamate receptors in the goldfish brain. Brain Res 834:142-145

Poli A, Beraudi A, Villani L, Storto M, Battaglia G, Di GG, V, Cappuccio I, Caricasole A, D'Onofrio M, Nicoletti F (2003) Group II metabotropic glutamate receptors regulate the vulnerability to hypoxic brain damage. J Neurosci 23:6023-6029

Saito T, Kujiraoka T, Yonaha T (1983) Connections between photoreceptors and horseradish peroxidase-injected bipolar cells in the carp retina. Vision Res 23:352-362

Saito T, Kujiraoka T, Yonaha T, Chino Y (1985) Re-examination of photoreceptor-bipolar connectivity patterns in carp retina: HRPEM and Golgi-EM studies. J Comp Neurol 236:141-160

Sakai HM, Naka KI (1983) Synaptic organization involving receptor, horizontal and On- and Off-center bipolar cells in the catfish retina. Vision Res 23:339-351

Saugstad JA, Kinzie JM, Mulvihill ER, Segerson TP, Westbrook GL (1994) Cloning and expression of a new member of the L-2-amino4-phosphonobutyric acid-sensitive class of metabotropic glutamate receptors. Mol Pharmacol 45:367-372

Schoepp DD, Jane DE, Monn JA (1999) Pharmacological agents acting at subtypes of metabotropic glutamate receptors. Neuropharmacology 38:1431-1476

Scholes JH (1975) Colour receptors, and their synaptic connexions, in the retina of a cyprinid fish. Philos Trans R Soc Lond Biol 270:61118

Schwartz EA (1993) L-glutamate conditionally modulates the $\mathrm{K}^{+}$ current of Muller glial cells. Neuron 10:1141-1149

Schwartz EA, Tachibana M (1990) Electrophysiology of glutamate and sodium co-transport in a glial cell of the salamander retina. J Physiol (Lond) 426:43-80

Shiells RA, Falk G, Naghshineh S (1981) Action of glutamate and aspartate analogues on rod horizontal and bipolar cells. Nature 294:592-594

Slaughter MM, Miller RF (1981) 2-Amino-4-phosphonobutyric acid: a new pharmacological tool for retinal research. Science 211:182185

Slaughter MM, Miller RF (1983) The role of excitatory amino acid transmitters in the mudpuppy retina: an analysis with kainic acid and N-methyl aspartate. J Neurosci 3:1701-1711

Stell WK (1967) The structure and relationships of horizontal cells and photoreceptor-bipolar synaptic complexes in goldfish retina. Am J Anat 121:401-424

Stell WK (1976) Functional polarization of horizontal cell dendrites in goldfish retina. Invest Ophthalmol 15:895-908

Stell WK (1978) Inputs to bipolar cell dendrites in goldfish retina. Sens Processes 2:339-349

Stell WK, Kretz R, Lightfoot DO (1982) Horizontal cell connectivity in goldfish. In: Drujan BJ, Laufer M (eds) The S-potential. Liss, New York, pp 51-75
Suzuki S, Kaneko A (1990) Identification of bipolar cell subtypes by protein kinase C-like immunoreactivity in the goldfish retina. Vis Neurosci 5:223-230

Takahashi K-I, Copenhagen DR (1992) APB suppresses synaptic input to retinal horizontal cells in fish: a direct action on horizontal cells modulated by intracellular pH. J Neurophysiol 67:1633-1642

Tanabe Y, Masu M, Ishii T, Shigemoto R, Nakanishi S (1992) A family of metabotropic glutamate receptors. Neuron 8:169-179

Tanabe Y, Nomura A, Masu M, Shigemoto R, Mizuno N, Nakanishi S (1993) Signal transduction, pharmacological properties, and expression patterns of two rat metabotropic glutamate receptors, mGluR3 and mGluR4. J Neurosci 13:1372-1378

Thoreson WB, Miller RF (1993) Membrane currents evoked by excitatory amino acid agonists in ON bipolar cells of the mudpuppy retina. J Neurophysiol 70:1326-1338

Thoreson WB, Ulphani JS (1995) Pharmacology of selective and nonselective metabotropic glutamate receptor agonists at L-AP4 receptors in retinal ON bipolar cells. Brain Res 676:93-102

Tian L, Kammermeier PJ (2006) G protein coupling profile of mGluR6 and expression of G[alpha] proteins in retinal ON bipolar cells. Vis Neurosci 23:909-916

Ueda Y, Iwakabe H, Masu M, Suzuki M, Nakanishi S (1997) The mGluR6 5' upstream transgene sequenc directs a cell-specific and developmentally regulated expression in retinal rod and ON-type cone bipolar cells. J Neurosci 17:3014-3023

Vardi N, Morigiwa K (1997) ON cone bipolar cells in rat express the metabotropic receptor mGluR6. Vis Neurosci 14:789-794

Vardi N, Matesic DF, Manning DR, Liebman PA, Sterling P (1993) Identification of a G-protein in depolarizing rod bipolar cells. Vis Neurosci 10:473-478

Vardi N, Duvoisin R, Wu G, Sterling P (2000) Localization of mGluR6 to dendrites of ON bipolar cells in primate retina. J Comp Neurol 423:402-412

Villegas GM (1960) Electron microscopic study of the vertebrate retina. J Gen Physiol 43 (6 Suppl):15-43

Wagner H-J (1980) Light-dependent plasticity of the morphology of horizontal cell terminals in cone pedicles of fish retinas. J Neurocytol 9:573-590

Yang X-L, Wu SM (1989) Effects of CNQX, APB, PDA and kynurenate on horizontal cells of the tiger salamander retina. Vis Neurosci 3:207-212

Yasui S, Yamada M, Djamgoz MBA (1990) Dopamine and 2-amino4-phosphonobutyrate differentially modify spectral responses of H1 horizontal cells in carp retina. Exp Brain Res 83:79-84

Yazulla S, Studholme KM (1992) Light-dependent plasticity of the synaptic terminals of $\mathrm{Mb}$ bipolar cells in goldfish retina. J Comp Neurol 320:521-530

Yazulla S, Studholme KM (2001) Neurochemical anatomy of the zebrafish retina as determined by immunocytochemistry. J Neurocytol 30:551592

Yazulla S, Studholme KM, Fan SF, Mora-Ferrer C (2001) Neuromodulation of voltage-dependent $\mathrm{K}^{+}$channels in bipolar cells: immunocytochemical and electrophysiological studies. Prog Brain Res 131:201-213

Young S, Rothbard J, Parker PJ (1988) A monoclonal antibody recognising the site of limited proteolysis of protein kinase $\mathrm{C}$. Inhibition of down-regulation in vivo. Eur J Biochem 173:247-252

Zhou ZJ, Fain GL, Dowling JE (1993) The excitatory and inhibitory amino acid receptors on horizontal cells isolated from the white perch retina. J Neurophysiol 70:8-19 